\title{
1-Methyl-4-phenyl-1,2,3,6-tetrahydropyride Neurotoxicity Is Attenuated in Mice Overexpressing Bcl-2
}

\author{
Lichuan Yang, ${ }^{1,3}$ Russell T. Matthews, ${ }^{1,3}$ Jörg B. Schulz, ${ }^{4}$ Thomas Klockgether, ${ }^{4}$ Andrew W. Liao, ${ }^{2}$ \\ Jean-Claude Martinou, ${ }^{5}$ John B. Penney, Jr., ${ }^{3}$ Bradley T. Hyman, ${ }^{2}$ and M. Flint Beal ${ }^{1,3}$ \\ ${ }^{1}$ Neurochemistry Laboratory, ${ }^{2}$ Alzheimer's Disease Research Laboratory, and ${ }^{3}$ Neurology Service, Massachusetts General \\ Hospital and Harvard Medical School, Boston, Massachusetts 02114, "Experimental Neuropharmacology Laboratory, \\ Department of Neurology, University of Tübingen, D-72076 Tübingen, Germany, and ${ }^{5}$ Glaxo Institute for Molecular Biology \\ S.A., CH-1228 Plan-les-Ouates, Geneva, Switzerland
}

The proto-oncogene $\mathrm{Bcl}-2$ rescues cells from a wide variety of insults. Recent evidence suggests that $\mathrm{Bcl}-2$ protects against free radicals and that it increases mitochondrial calciumbuffering capacity. The neurotoxicity of 1-methyl-4-phenyl1,2,3,6-tetrahydropyride (MPTP) is thought to involve both mitochondrial dysfunction and free radical generation. We therefore investigated MPTP neurotoxicity in both Bcl-2 overexpressing mice and littermate controls. MPTP-induced depletion of dopamine and loss of $\left[{ }^{3} \mathrm{H}\right]$ mazindol binding were significantly attenuated in $\mathrm{Bcl}-2$ overexpressing mice. Protection was more profound with an acute dosing regimen than with daily
MPTP administration over 5 d. 1-Methyl-4-phenylpyridinium $\left(\mathrm{MPP}^{+}\right.$) levels after MPTP administration were similar in Bcl-2 overexpressing mice and littermates. Bcl-2 blocked $\mathrm{MPP}^{+}$ induced activation of caspases. MPTP-induced increases in free 3-nitrotyrosine levels were blocked in $\mathrm{Bcl}-2$ overexpressing mice. These results indicate that $\mathrm{Bcl}-2$ overexpression protects against MPTP neurotoxicity by mechanisms that may involve both antioxidant activity and inhibition of apoptotic pathways.

Key words: MPTP; Parkinson's disease; apoptosis; free radicals; 3-nitrotyrosine; caspases; Bcl-2
The neurotoxin 1-methyl-4-phenyl-1,2,3,6-tetrahydropyridine (MPTP) results in a clinical syndrome closely resembling Parkinson's disease (PD) in both man and primates (Bloem et al., 1990). This meperidine analog is metabolized to 1-methyl-4phenylpyridinium $\left(\mathrm{MPP}^{+}\right)$by the enzyme monoamine oxidase $\mathrm{B}$. $\mathrm{MPP}^{+}$is subsequently taken up selectively by dopaminergic terminals and concentrated in neuronal mitochondria in the substantia nigra pars compacta $(\mathrm{SNpc})$. $\mathrm{MPP}^{+}$binds to and inhibits complex I of the electron transport chain (Tipton and Singer, 1993). It may also cause irreversible inactivation of complex I by generating free radicals (Cleeter et al., 1992). $\mathrm{MPP}^{+}$increases superoxide production in isolated bovine submitochondrial particles in vitro (Hasegawa et al., 1990) and in vivo (Sriram et al., 1997). MPTP-induced damage is attenuated in transgenic mice overexpressing superoxide dismutase, implicating free radical generation in its neurotoxicity (Przedborski et al., 1992).

The proto-oncogene Bcl-2 was initially characterized because of its ability to inhibit apoptosis. Bcl-2 is widely expressed in the nervous system and is localized to the outer mitochondrial membrane, endoplasmic reticulum, and nuclear membrane (Krajewski et al., 1993). Bcl-2 expression inhibits apoptosis in neural cells induced by a variety of stimuli (Bredesen, 1995). It also inhibits necrotic neural cell death in some paradigms, such as oxidative neural cell death induced by depletion of glutathione (Kane et al., 1995). Bcl-2 protects cells from the lethal effects of $\mathrm{H}_{2} \mathrm{O}_{2}$ or tertbutyl hydroperoxide in a dose-dependent manner (Hocken-

\footnotetext{
Received Jan. 5, 1998; revised July 29, 1998; accepted August 3, 1998.

This work was supported by National Institutes of Health Grants NS10878, NS31579, and AG12992, and Deutsche Forschungsgemeinschaft Grant SFB430 (J.B.S.). We thank Sharon Melanson for her secretarial assistance.

Correspondence should be addressed to Dr. M. Flint Beal, Neurology Service/ WRN 408, Massachusetts General Hospital, 32 Fruit Street, Boston, MA 02114. Copyright (C) 1998 Society for Neuroscience $0270-6474 / 98 / 188145-08 \$ 05.00 / 0$
}

berry et al., 1993; Kane et al., 1993). It also protects neural cells from cyanide-aglycemia-induced lipid peroxidation, compromised mitochondrial respiration, and delayed cell death (Myers et al., 1995), as well as from AMPA toxicity in cortical cultures (White et al., 1997). It increases the capacity of neural cell mitochondria to accumulate calcium (Murphy et al., 1996). A critical role may be in regulation of membrane potential and volume homeostasis of mitochondria in response to apoptotic or necrotic stimuli (Vander Heiden et al., 1997). A recent study showed that $\mathrm{Bcl}-2$ maintains the mitochondrial membrane potential, enhances $\mathrm{H}^{+}$efflux after treatment with either $\mathrm{Ca}^{2+}$ or tertbutyl hydroperoxide, and prevents activation of the mitochondrial permeability transition (Shimizu et al., 1998).

Because mitochondrial dysfunction and oxidative injury play a role in the pathogenesis of MPTP neurotoxicity, we investigated whether MPTP neurotoxicity is attenuated in Bcl-2 overexpressing mice. The mice have a neuron-specific enolase (NSE) promoter fused to human Bcl-2 cDNA (Martinou et al., 1994). They overexpress Bcl-2 in multiple tissues, including the SNpc. Previous work showed that they are resistant to permanent ischemia induced by middle cerebral artery occlusion (Martinou et al., 1994) and that crossing them into a transgenic mouse model of amyotrophic lateral sclerosis extends survival (Kostic et al., 1997).

We examined the effects of both acute and chronic daily dosing regimen of MPTP in Bcl-2 overexpressing mice compared with littermate controls. Chronic (daily administration over 5 d) administration of MPTP induces apoptotic cell death in the SNpc of mice (Tatton and Kish, 1997), whereas no evidence of apoptosis was found with a more acute dosing regimen (Jackson-Lewis et al., 1995). We suspected that neuroprotection in Bcl-2 overexpressing mice would be more profound with a chronic dosing regimen. Surprisingly, there was almost complete protection 
Figure 1. Effects of MPTP administered at $15 \mathrm{mg} / \mathrm{kg}$ intraperitoneally every $2 \mathrm{hr}$ for 4 doses on dopamine, DOPAC, and HVA in wild-type and Bcl-2 overexpressing mice. ${ }^{* *} p<0.01$ $* * * p<0.001$ compared with MPTP in controls.
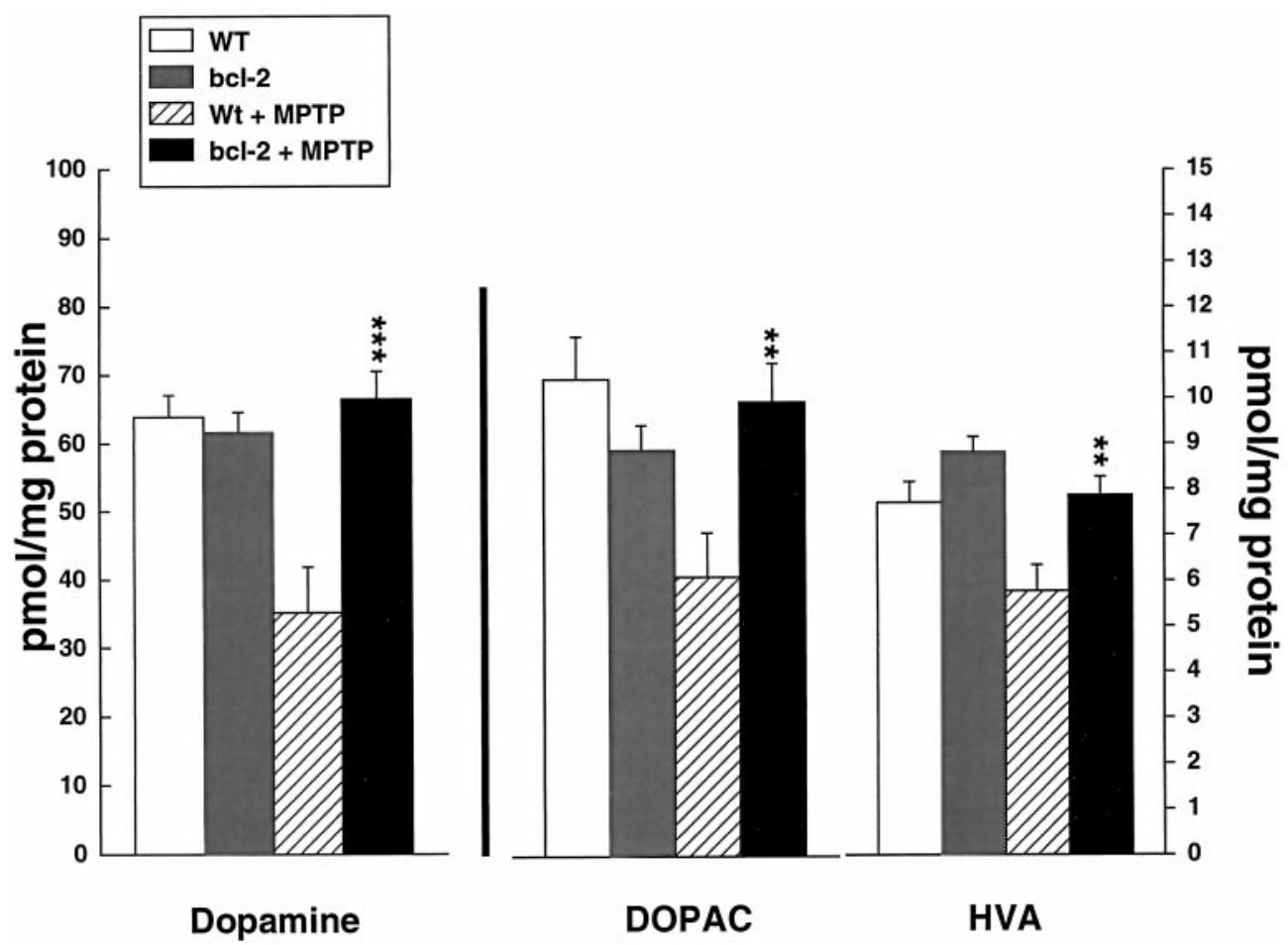
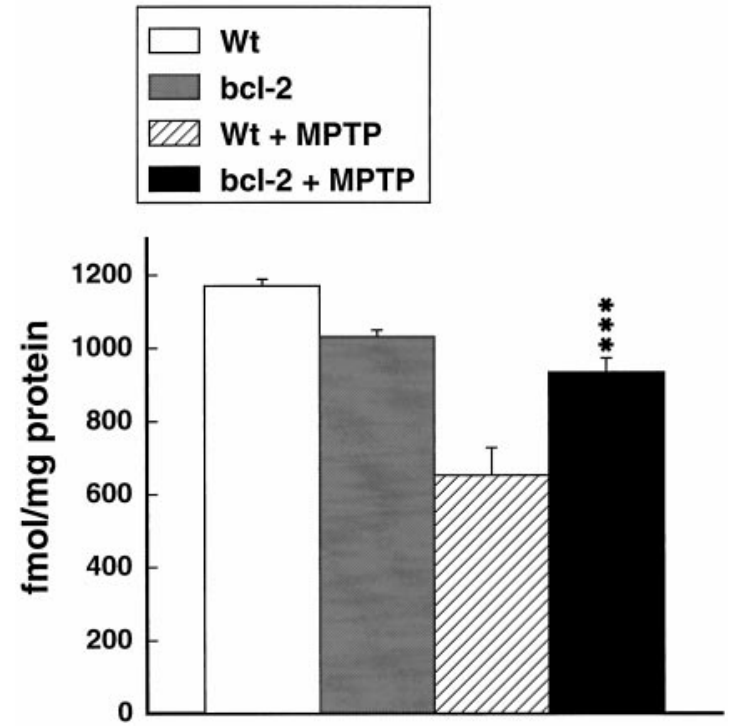

Figure 2. Effects of MPTP administered at $15 \mathrm{mg} / \mathrm{kg}$ intraperitoneally every $2 \mathrm{hr}$ for 4 doses on $\left[{ }^{3} \mathrm{H}\right]$ mazindol binding in the striatum in wild-type and $\mathrm{Bcl}-2$ overexpressing mice. ${ }^{* * *} p<0.001$ compared with MPTP in controls.

against MPTP neurotoxicity induced by an acute dosing regimen, whereas there was only partial protection with a chronic dosing regimen. We investigated the mechanism of neuroprotection in Bcl-2 overexpressing mice by showing that increases in 3-nitrotyrosine, a marker of oxidative damage, were attenuated and that caspase activation was inhibited.

\section{MATERIALS AND METHODS}

Human Bcl-2 overexpressing transgenic animals. Transgenic mice in which neurons overexpress the human $\mathrm{Bcl}-2$ gene were generated using the NSE promoter by Martinou et al. (1994). We received male founders (strain NSE73A) and bred them with the same strain female mice to obtain the hemizygous transgenic offsprings as assessed by PCR analysis of the DNA extracted from tissue taken from their tails. These mice are difficult to breed because females have an imperforate vagina and $50 \%$ of males are sterile. Wild-type littermates were used as controls.

MPTP in PBS was administered using either a chronic dosing regimen of $20 \mathrm{mg} / \mathrm{kg}$ intraperitoneally every $24 \mathrm{hr}$ for five doses or an acute dosing regimen of $15 \mathrm{mg} / \mathrm{kg}$ intraperitoneally every $2 \mathrm{hr}$ for four doses $(n=$ 10-12 mice in each group). Control animals in both paradigms were treated with a volume of PBS equal to the injection volume in the MPTP-treated animals. All animals in both paradigms were killed by decapitation $7 \mathrm{~d}$ after the last injection. For each mouse, one of the two striata was dissected, immediately frozen on dry ice, and stored at $-80^{\circ} \mathrm{C}$ for measurement of dopamine and its metabolites. The other hemiforebrain was frozen in dry ice-cooled isopentane and sectioned on cryostat at $20 \mu \mathrm{m}$ for dopamine transporter ligand binding. The rest of the brain, including the mesencephalon, was placed into chilled $4 \%$ paraformaldehyde in PBS, fixed at $4^{\circ} \mathrm{C}$ for $24 \mathrm{hr}$, and then cryoprotected in $20 \%$ glycerol at $4^{\circ} \mathrm{C}$.

Mice treated acutely with three doses of $15 \mathrm{mg} / \mathrm{kg}$ MPTP every $2 \mathrm{hr}$ were killed at 3 and $6 \mathrm{hr}$ after the last dose ( $n=6$ per group). The two striata were rapidly dissected and frozen at $-80^{\circ} \mathrm{C}$ for $\mathrm{MPP}^{+}$measurements. To evaluate the effects of MPTP on 3-nitrotyrosine levels, mice were injected with either saline or MPTP at $15 \mathrm{mg} / \mathrm{kg}$ intraperitoneally every $2 \mathrm{hr}$ for four doses. Eight animals in each group were killed at $3 \mathrm{hr}$ after the last dose (the time point at which we see a maximal increase in 3-nitrotyrosine levels after MPTP).

Stereological counts of tyrosine hydroxylase neurons. Eight Bcl-2 and seven littermate control mice were transcardially perfused with $4 \%$ buffered paraformaldehyde. Total neuron number in the SNpc was assessed using stereological principles. The nigra was serially sectioned, and every sixth section was immunostained with anti-tyrosine hydroxylase $(\mathrm{TH})$. The number of TH-positive neurons was assessed using the optical dissector technique and a systemic random sampling scheme using the stereology subroutines of Bioquant (Nashville, TN) Image Analysis Software. The volume of the SNpc was calculated by measuring the area on each section and using the Cavalieri principle.

Neurochemical analysis. Dissected striatal tissues were sonicated and centrifuged in chilled $0.1 \mathrm{M}$ perchloric acid (PCA) $(30 \mu \mathrm{l} / \mathrm{mg}$ tissue). The supernatants were evaluated for levels of dopamine, 3,4dihydroxyphenylacetic acid (DOPAC), homovanillic acid (HVA), $p$-tyrosine, and 3-nitrotyrosine by HPLC with 16-electrode electrochemical detection as described previously (Beal et al., 1990). Concentrations of dopamine and metabolites are expressed as picomoles per milligram of 

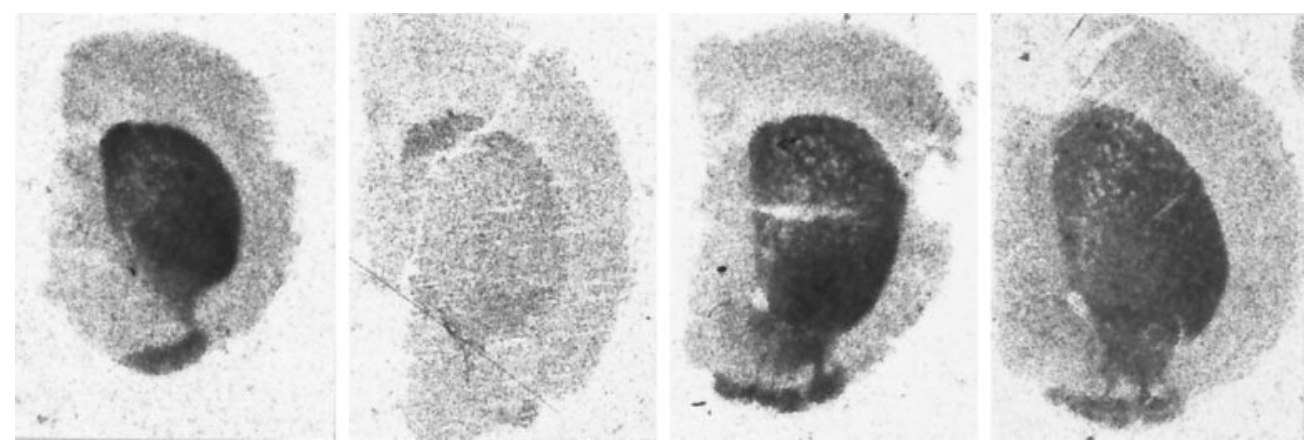

Figure 3. Representative autoradiographs of total $\left[{ }^{3} \mathrm{H}\right]$ mazindol binding in the striatum in wild-type and $\mathrm{Bcl}-2$ overexpressing mice after acute administration of MPTP. Left, Untreated wild-type mouse. Midleft, MPTPtreated wild-type mouse. Midright, Untreated $\mathrm{Bcl}-2$ transgenic mouse. Right, MPTP-treated Bcl-2 transgenic mouse.

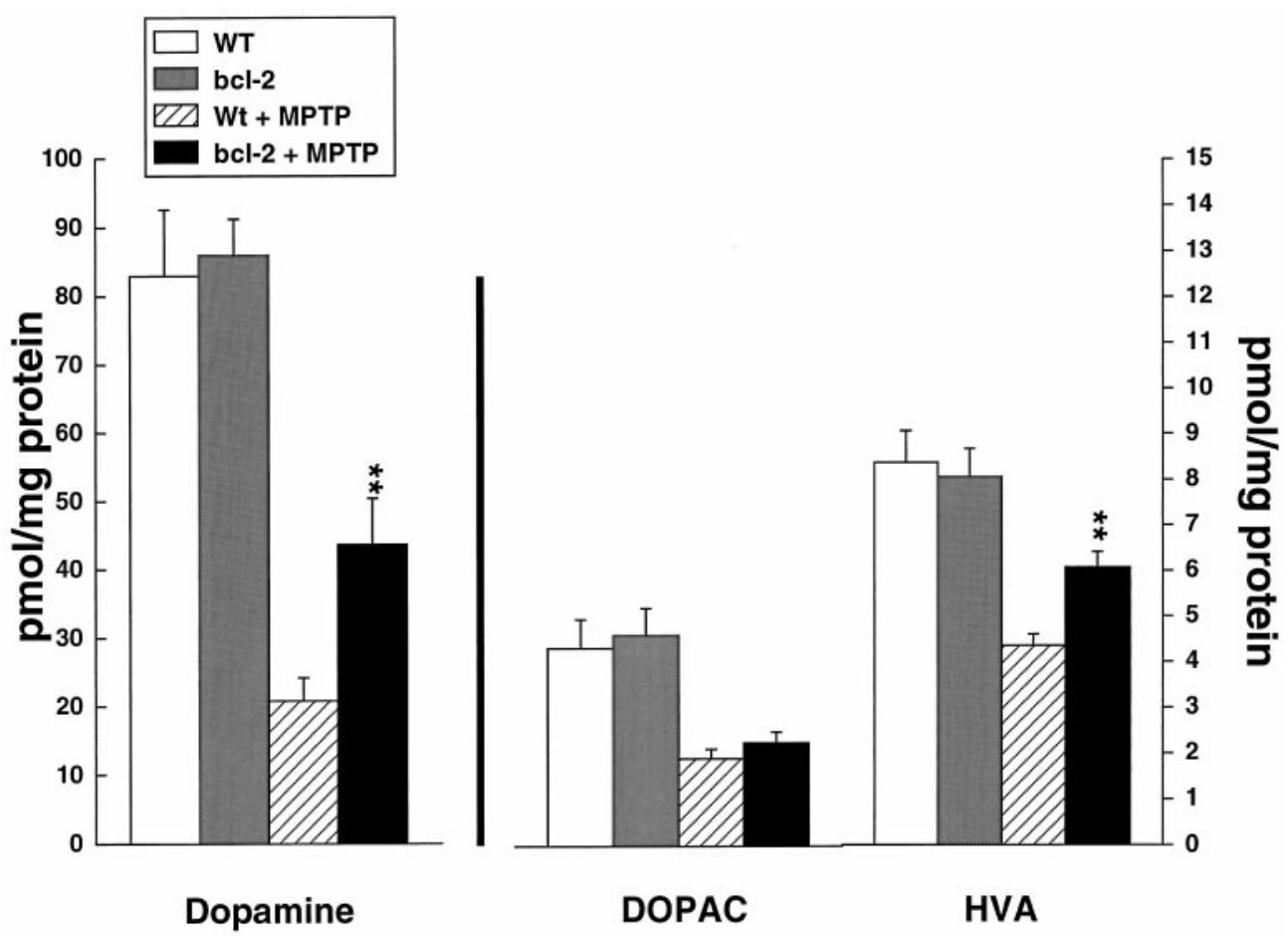

Figure 4. Effects of MPTP administered at $20 \mathrm{mg} / \mathrm{kg}$ intraperitoneally daily for 5 days on dopamine, DOPAC, and HVA in wild-type and Bcl-2 overexpressing mice. ${ }^{* *} p<0.01$ compared with MPTP in controls.

protein. Free 3-nitrotyrosine data are expressed as ratios of 3-nitrotyrosine per $p$-tyrosine to normalize for differing brain concentrations of tyrosine. MPP ${ }^{+}$levels (nanograms per milligram tissue wet weight) were quantified by HPLC with UV detection at $295 \mathrm{~nm}$. Samples were sonicated in $0.1 \mathrm{M}$ PCA, and an aliquot of supernatant was injected onto a Brownlee aquapore X03-224 cation exchange column (Rainin, Ridgefield, NJ). Samples were eluted isocratically with $90 \% 0.1 \mathrm{M}$ acetic acid, $75 \mathrm{~mm}$ triethylamine-HCL, pH 2.35 adjusted with formic acid, and $10 \%$ acetonitrile. The flow rate was $1 \mathrm{ml} / \mathrm{min}$.

Dopamine transporter binding autoradiography. Twenty micrometer striatal sections were prewashed $5 \mathrm{~min}$ in ice-cold buffer $(50 \mathrm{~mm}$ Tris$\mathrm{HCl}, 5 \mathrm{~mm} \mathrm{KCl}$, and $300 \mathrm{~mm} \mathrm{NaCl}, \mathrm{pH} \mathrm{7.9)}$ and then were incubated without drying in the ice-cold buffer containing $6 \mathrm{nM}\left[{ }^{3} \mathrm{H}\right]$ mazindol and $300 \mathrm{~nm}$ desipramine for $60 \mathrm{~min}$ (nonspecific binding determined in the presence of $10 \mu \mathrm{M}$ nomifensine) (Javitch et al., 1983). The slices were washed twice for $3 \mathrm{~min}$ in buffer chilled to $4^{\circ} \mathrm{C}$ and quickly dipped in cold distilled water. Then, they were hot-air dried and exposed to Hyperfilm- ${ }^{3} \mathrm{H}$ (Amersham, Arlington Heights, IL) at $4^{\circ} \mathrm{C}$ for 2 weeks. Films were developed with D19 (Eastman Kodak, Rochester, NY) developer. The films were analyzed with a video-based computerized image analysis system (MCID; Imaging Research, Inc., St. Catherine's, Ontario, Canada). The total striatal $\left[{ }^{3} \mathrm{H}\right]$ mazindol binding (femtomoles per milligram of protein) was calculated using calibrated plastic ${ }^{14} \mathrm{C}$ standards (Penney et al., 1981; Pan et al., 1983).

Caspase activation. To examine for caspase activation, we injected $\mathrm{MPP}^{+}$, the active metabolite of MPTP, into the anterior striatum of wild-type and Bcl-2 overexpressing mice. $\mathrm{MPP}^{+}$(Research Biochemicals, Wayland, MA) was dissolved in PBS at a concentration of $15 \mathrm{~mm}$, and $0.75 \mu \mathrm{l}$ was injected. Four mice were killed at 12 and $24 \mathrm{hr}$ after striatal $\mathrm{MPP}^{+}$or saline, respectively. The striata were dissected from a 2-mm-thick slice and lysed on ice in $50 \mathrm{~mm}$ Tris- $\mathrm{HCl}, \mathrm{pH} 8.0$, containing $120 \mathrm{~mm} \mathrm{NaCl}, 0.5 \% \mathrm{NP}-40,5 \mathrm{~mm}$ EDTA, $100 \mu \mathrm{g} / \mathrm{ml}$ PMSF, $2 \mu \mathrm{g} / \mathrm{ml}$ aprotinin, and $10 \mu \mathrm{g} / \mathrm{ml}$ leupeptin, followed by centrifugation at $10,000 \times g$ for $10 \mathrm{~min}$. Samples were diluted to $1 \mu \mathrm{g} / \mu \mathrm{l}$ protein and 20 $\mu \mathrm{g} /$ lane subjected to SDS-PAGE on $12 \%$ polyacrylamide gels. After electrophoresis and electroblotting to nitrocellulose membranes, the blots were blocked in $250 \mathrm{~mm}$ Tris- $\mathrm{HCl}, \mathrm{pH} 8.0,120 \mathrm{~mm} \mathrm{NaCl}, 10 \%$ nonfat dry milk, $5 \%$ BSA, $1 \%$ normal goat serum, $0.5 \%$ Tween 20 , and $0.1 \%$ azide for $30 \mathrm{~min}$. Next, the blots were incubated in the first antibody (anti-ICH- $\mathrm{L}_{\mathrm{L}}$; 1:1000; Transduction Laboratories, Lexington, $\mathrm{KY}$ ) at $4^{\circ} \mathrm{C}$ overnight. After three washes in PBS (containing $0.05 \%$ Tween 20), the membranes were incubated with secondary alkaline phosphataseconjugated antibody for $1 \mathrm{hr}$, washed three times in PBS, and stained with $0.2 \mathrm{mg} / \mathrm{ml}$ nitroblot tetrazolium chloride and $0.3 \mathrm{mg} / \mathrm{ml}$ 5-bromo-4chloro-3-indolyl-phosphate in $0.1 \mathrm{M}$ Tris- $\mathrm{HCl}, \mathrm{pH} 9.5$, containing $50 \mathrm{~mm}$ $\mathrm{MgCl}_{2}$ and $100 \mathrm{~mm} \mathrm{NaCl}$.

Statistical analysis. Statistical significance of differences between groups was determined via one-way ANOVA, followed by Fisher PLSD post hoc test to compare group means. The correlation of striatal $\left[{ }^{3} \mathrm{H}\right]$ mazindol binding and dopamine levels was analyzed by Fisher's $\mathrm{R}$ to $\mathrm{Z}$ test.

\section{RESULTS}

Because NSE73A Bcl-2 mice have hypertrophic brains with increased numbers of neurons in some cell groups, we performed 

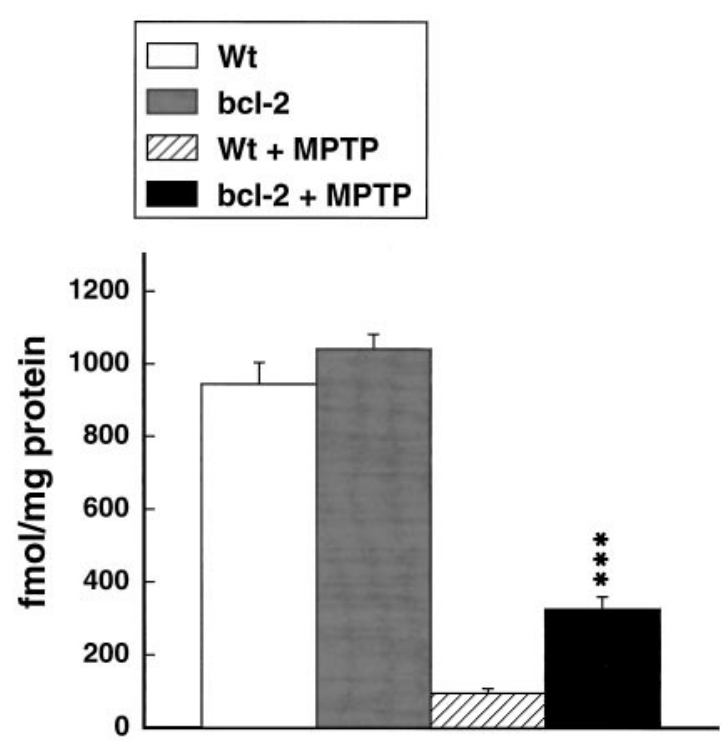

Figure 5. Effects of MPTP administered at $20 \mathrm{mg} / \mathrm{kg}$ intraperitoneally daily for 5 days on $\left[{ }^{3} \mathrm{H}\right]$ mazindol binding in the striatum in wild-type and $\mathrm{Bcl}-2$ overexpressing mice. ${ }^{* * *} p<0.001$ compared with MPTP in controls.

stereological cell counts of $\mathrm{TH}$-immunopositive neurons in the SNpc of Bcl-2 overexpressing mice and littermate controls. Although there was a small increase in $\mathrm{TH}$-immunopositive neurons in Bcl-2 mice compared with normal controls, the result was not significant. The number of TH-immunopositive neurons in the SNpc on one side in the controls was $5347 \pm 433$, and the number was $5125 \pm 265(p=0.68)$ in Bcl-2 overexpressing mice. Similarly, there were no significant differences in striatal dopamine levels of $\left[{ }^{3} \mathrm{H}\right]$ mazindol binding at baseline (Figs. 1, 2).

The effects of MPTP administered acutely at a dose of 15 $\mathrm{mg} / \mathrm{kg}$ intraperitoneally every $2 \mathrm{hr}$ for 4 doses on dopamine, DOPAC, and HVA in wild-type (littermate) and Bcl-2 overexpressing mice are shown in Figure 1. There was significant, almost complete protection against depletions of dopamine, DOPAC, and HVA in the Bcl-2 overexpressing mice. Similarly, $\left[{ }^{3} \mathrm{H}\right]$ mazindol binding in the striatum also showed almost complete protection (Fig. 2). Representative autoradiograms are shown in Figure 3.

The effects of administration of MPTP at a dose of $20 \mathrm{mg} / \mathrm{kg}$ daily for 5 consecutive days are shown in Figure 4. MPTP produced significant depletion of dopamine, DOPAC, and HVA. The depletions were significantly attenuated in the Bcl-2 overexpressing mice, but protection was not as complete as that seen with the acute dosing regimen. Similarly, $\left[{ }^{3} \mathrm{H}\right]$ mazindol binding in the striatum showed partial significant protection that was not as profound as that seen with the acute dosing regimen (Fig. 5). Representative autoradiograms are shown in Figure 6.

$\mathrm{MPP}^{+}$levels were $3.74 \pm 0.63$ versus $4.56 \pm 1.24 \mathrm{ng} / \mathrm{mg}$ wet weight at $3 \mathrm{hr}$ in control and $\mathrm{Bcl}-2$ mice, respectively $(p=0.55)$. At $6 \mathrm{hr}, \mathrm{MPP}^{+}$levels were $0.97 \pm 0.57$ and $0.53 \pm 0.14 \mathrm{ng} / \mathrm{mg}$ wet weight in control and Bcl-2 overexpressing mice, respectively $(p=0.48)$. As shown in Figure 7, there was no difference in free 3-nitrotyrosine levels in Bcl-2 overexpressing mice compared with wild-type mice receiving saline. After administration of MPTP, there was a significant increase in free 3-nitrotyrosine levels in wild-type mice, which was significantly attenuated in Bcl-2 overexpressing mice.

By Western blot analysis, anti-ICH- $1_{\mathrm{L}}$ (Nedd2/caspase-2) rec- ognized a major band at $\sim 51 \mathrm{kDa}$ in striatal lysates and, infrequently, a minor band at $45 \mathrm{kDa}$ (Fig. 8). This apparent molecular weight of $51 \mathrm{kDa}$ is in agreement with that calculated from the predicted sequence of the Nedd2 protein (Kumar et al., 1994; Harvey et al., 1997). $\mathrm{MPP}^{+}$induced an upregulation of this protein at 12 and $24 \mathrm{hr}$ in wild-type animals and to a lesser extent in Bcl-2 overexpressing mice. Further, a cleavage product of $\sim 24$ $\mathrm{kDa}$ was detectable by Western blotting in wild-type animals but not in Bcl-2 mice.

\section{DISCUSSION}

Bcl-2 is a protein that inhibits both apoptotic and necrotic cell death. Although the specific mechanism of action of Bcl-2 is unknown, it can either detoxify or decrease the production of reactive oxygen species (Kane et al., 1993; Hockenberry et al., 1993; Lawrence et al., 1996). There is a direct antioxidant effect of Bcl-2 in PC12 rat pheochromocytoma cells (Tyurina et al., 1997). Neural cells expressing Bcl-2 have elevated levels of reduced glutathione/oxidized glutathione and $\mathrm{NADH} / \mathrm{NAD}^{+}$, indicating a shift in cellular redox potential to a more reduced state (Ellerby et al., 1996). Bcl-2 causes a redistribution of glutathione to the nucleus (Voehringer et al., 1998). Bcl-2 also has beneficial effects on mitochondrial function. It enhances the mitochondrial membrane potential and improves ATP/ADP ratios (Hennet et al., 1993; Smets et al., 1994) and delays ATP depletion induced by growth factor withdrawal (Garland and Halestrap, 1997). Overexpression of Bcl-2 enhances the mitochondrial calcium uptake potential of neural cells (Murphy et al., 1996), and it inhibits mitochondrial release of calcium (Baffy et al., 1993). Bcl-2 expression inhibits the mitochondrial transition pore and release of an apoptogenic protease (Susin et al., 1996; Zamzami et al., 1996; Shimizu et al., 1998). Bcl-2 expression also blocks the release of cytochrome c from mitochondria (Kluck et al., 1997; Yang et al., 1997), which is linked to apoptosis (Liu et al., 1996). The related protein $\mathrm{Bcl}-\mathrm{x}_{\mathrm{L}}$ also blocks cytochrome $\mathrm{c}$ release by directly binding to cytochrome c (Kharbanda et al., 1997) and by blocking rupture of the outer mitochondrial membrane (Vander Heiden et al., 1997). Bcl-2 targets the protein kinase raf-1 to mitochondria where it helps to block apoptosis (Wang et al., 1996). In other studies, it blocks the activation of caspases, indicating that it acts upstream of caspases in the cell death pathway (Chinnaiyan et al., 1996; Srinivasan et al., 1996). Bcl-2, as well as the Bcl-2 analog Bcl- $\mathrm{x}_{\mathrm{L}}$, forms ion channels in synthetic lipid membranes (Minn et al., 1997; Schendel et al., 1997), and it inhibits Bax channelforming activity (Antonsson et al., 1997). Bcl- $\mathrm{x}_{\mathrm{L}}$ inhibits mitochondrial swelling, regulates membrane potential in response to both necrotic and apoptotic stimuli (Vander Heiden et al., 1997), and inhibits a loss of mitochondrial membrane potential by regulating proton flux (Shimizu et al., 1998).

Substantial evidence implicates mitochondrial dysfunction and free radical generation in MPTP neurotoxicity. Because Bcl-2 expression can modify both of these processes, we examined whether MPTP neurotoxicity is reduced in mice overexpressing Bcl-2. Both necrotic and apoptotic cell death mechanisms may play a role in MPTP neurotoxicity, depending on the severity of the insult. In PC12 cells, a high dose of $\mathrm{MPP}^{+}$induces rapid necrotic cell death, whereas lower doses produce delayed apoptotic cell death (Hartley et al., 1994). MPTP administered at a dose of $20 \mathrm{mg} / \mathrm{kg}$ for $5 \mathrm{~d}$ induced apoptotic cell death in the SNpc, as documented using both in situ end labeling with terminal deoxynucleotidyl transferase and staining for chromatin condensation with acridine orange (Tatton and Kish, 1997). In contrast, an 

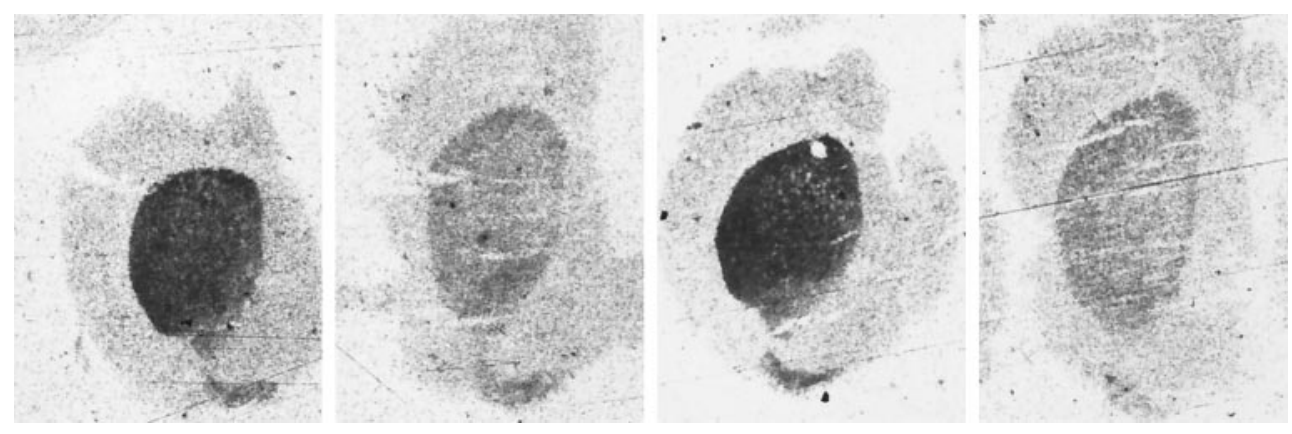

Figure 6. Representative autoradiographs of total $\left[{ }^{3} \mathrm{H}\right]$ mazindol binding in the striatum in wild-type and $\mathrm{Bcl}-2$ overexpressing mice after chronic administration of MPTP. Left, Untreated wildtype mouse. Midleft, MPTP-treated wild-type mouse. Midright, Untreated $\mathrm{Bcl}-2$ transgenic mouse. Right, MPTPtreated Bcl-2 transgenic mouse.

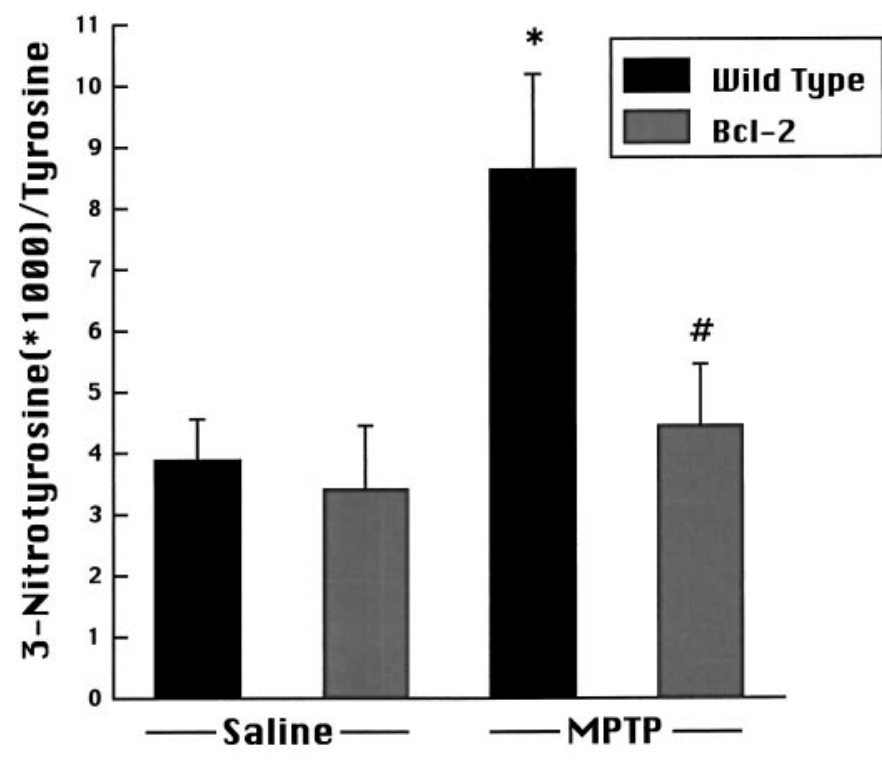

Figure 7. Effects of MPTP administration on 3-nitrotyrosine concentrations in wild-type and $\mathrm{Bcl}-2$ overexpressing mice. MPTP induced a significant increase in 3-nitrotyrosine at $3 \mathrm{hr}$ after the last dose compared with saline treated controls, which was significantly attenuated in $\mathrm{Bcl}-2$ overexpressing mice. ${ }^{*} p<0.05$ compared with saline; $\# p<0.05$ compared with MPTP-treated wild type.

acute dosing regimen of MPTP did not show evidence of apoptotic nuclei (Jackson-Lewis et al., 1995). We therefore hypothesized that an acute dosing regimen of MPTP would be more likely to induce necrotic cell death, and a more chronic dosing regimen administered daily would be more likely to induce apoptotic cell damage.

In the present experiments, to our surprise, there was almost complete protection from MPTP-induced decreases in dopamine levels and $\left[{ }^{3} \mathrm{H}\right]$ mazindol binding induced by acute administration of MPTP in mice overexpressing Bcl-2. Although the fall in $\left[{ }^{3} \mathrm{H}\right]$ mazindol binding seen after MPTP lesions could represent downregulation of dopamine transporter numbers or affinities in surviving dopamine terminals, the fact that MPTP is known to kill dopamine neurons makes it most likely that this result represents protection of dopamine neurons and their terminals by Bcl-2. There was also complete protection against MPTPinduced depletions of the dopamine metabolites DOPAC and HVA. The neuroprotective effects were not attributable to an alteration in numbers of substantia nigra neurons, as shown by stereological cell counts of $\mathrm{TH}$ neurons. After chronic daily administration of MPTP, there was significant partial protection against depletions of dopamine, HVA, and $\left[{ }^{3} \mathrm{H}\right]$ mazindol binding; however, it was much less marked than the protection seen with the acute dosing regimen. These results indicate that $\mathrm{Bcl}-2$ protects against both acute and chronic dosing regimens of MPTP neurotoxicity, but it is much more effective against an acute dosing regimen in which necrotic cell death would be expected to predominate. This is of course unexpected, because Bcl-2 is well known to have anti-apoptotic properties. However, if a primary mechanism is to stabilize mitochondria and induce antioxidant effects, one might well expect protection against both necrotic and apoptotic cell damage.

The mechanism of neuroprotective effects of Bcl-2 overexpression was investigated. There were no effects on $\mathrm{MPP}^{+}$levels in the Bcl-2 expressing mice compared with littermate controls, indicating that the neuroprotective effects of Bcl-2 are not mediated by an alteration in MPTP uptake or metabolism to $\mathrm{MPP}^{+}$. There also were no significant differences in $\left[{ }^{3} \mathrm{H}\right]$ mazindol binding in Bcl-2 expressing mice compared with littermate controls at baseline, indicating no change in the dopamine transporter.

Recent evidence indicates that Bcl-2 acts upstream of caspase proteases in programmed cell death to inhibit their activation. Bcl-2 blocks release of cytochrome $\mathrm{c}$ and subsequent activation of caspases in vitro (Kluck et al., 1997; Yang et al., 1997). In the cytosol, cytochrome c binds to apoptotic protease activating factor-1, the mammalian homolog of CED-4, which may trigger the activation of caspase-3 (Zou et al., 1997). After MPP ${ }^{+}$ injections, our extracts show a major band at $51 \mathrm{kDa}$, agreeing with the predicted molecular weight of Nedd2 (Kumar et al., 1994; Harvey et al., 1997). This probably reflects damage to both dopaminergic terminals and intrinsic striatal neurons, because $\mathrm{MPP}^{+}$injections result in striatal damage (Storey et al., 1994). Striatal $\mathrm{MPP}^{+}$injections lead to an upregulation of this protein, which was reduced in Bcl-2 overexpressing mice. Activation of Nedd 2 requires the cleavage of the $51 \mathrm{kDa}$ precursor molecule into subunits of 19 and $12 \mathrm{kDa}$ (Harvey et al., 1997). Cleavage of Nedd 2 has been reported in other neuronal cell death paradigms, namely in the trophic factor withdrawal-induced apoptosis of differentiated PC12 cells (Troy et al., 1997) and staurosporineinduced apoptosis of neuronal GT1-7 cells (Srinivasan et al., 1996). At 12 and $24 \mathrm{hr}$ after injection of $\mathrm{MPP}^{+}$into the striatum, a cleavage product of $\sim 24 \mathrm{kDa}$ was detectable in wild-type, but not in Bcl-2 transgenic, animals. At present, we cannot explain the discrepancy between the predicted molecular weight of the cleavage products (12 and $19 \mathrm{kDa}$ ) and the observed $24 \mathrm{kDa}$ band. Because this cleavage product only occurred after upregulation of Nedd 2 protein and the cleavage was blocked by Bcl-2, we feel that it represents a cleaved subunit of Nedd2. Possibly, this cleavage product is an intermediate form of the 19 or $12 \mathrm{kDa}$ subunit.

Although neuronal Bcl-2 overexpression did not block upregulation of Nedd 2 protein, the cleavage of Nedd2 into active subunits was completely blocked, consistent with recent results 

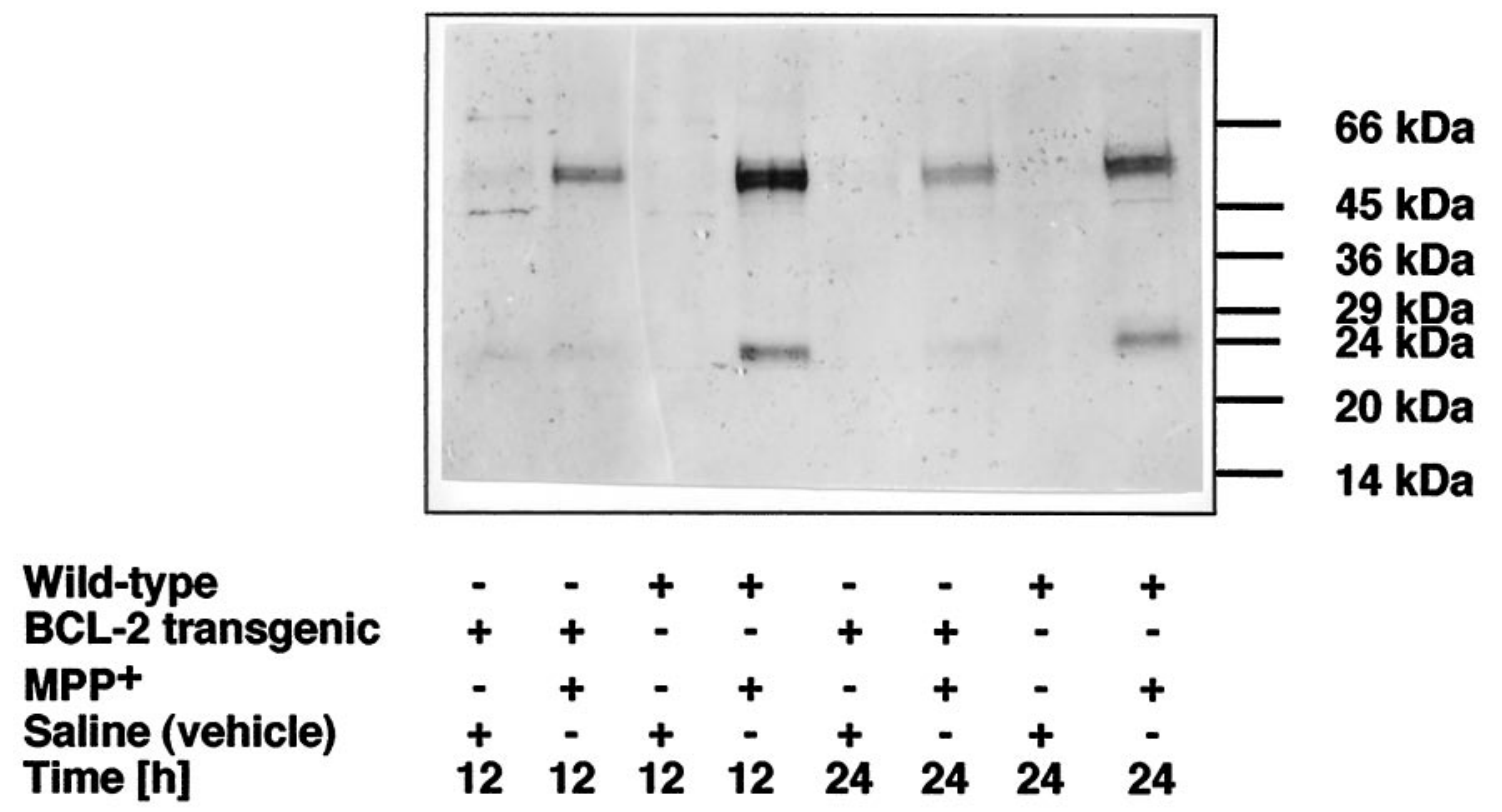

Figure 8. Striatal $\mathrm{MPP}^{+}$injections induce Bcl-2-sensitive activation of caspase-2. $\mathrm{MPP}^{+}$or vehicle (saline) were injected into the striatum of wild-type or Bcl-2 transgenic animals, and immunoblot analysis of striatal lysates was performed at 12 and $24 \mathrm{hr}$ after injection. The $51 \mathrm{kDa}$ band corresponds to caspase-2 $\left(\mathrm{Nedd} 2 / \mathrm{ICH}-1_{\mathrm{L}}\right)$, and the $24 \mathrm{kDa}$ band represents a cleaved product of caspase- 2 .

(Srinivasan et al., 1996) showing that Bcl-2 blocks apoptosis by preventing processing of the proforms of caspases into the active forms. These findings therefore provide in vivo evidence linking $\mathrm{MPP}^{+}$to caspase activation and showing that Bcl-2 acts upstream to prevent this activation.

We also examined whether overexpression of Bcl-2 could inhibit MPTP-induced oxidative damage in vivo. We showed previously that MPTP neurotoxicity is associated with increases in striatal concentrations of free 3-nitrotyrosine, a marker of oxidative damage mediated by peroxynitrite (Schulz et al., 1995). Furthermore, we and others found that neuronal nitric oxide synthase inhibitors, which block the generation of peroxynitrite, produce neuroprotection against MPTP neurotoxicity in both mice and primates (Schulz et al., 1995; Hantraye et al., 1996; Przedborski et al., 1996). In the present study, we found that MPTP-induced increases in free 3-nitrotyrosine were significantly attenuated in mice overexpressing Bcl-2. These data therefore provide in vivo evidence that one mechanism of the neuroprotective effects of $\mathrm{Bcl}-2$ is by inhibiting oxidative damage.

Our results are consistent with recent studies that showed that expression of Bcl-2 can inhibit lipid peroxidation and cyanideaglycemic-induced cell death in vitro (Myers et al., 1995). Overexpression of Bcl-2 with herpes simplex vectors enhances neuronal survival in cultured neurons exposed to glutamate and hypoglycemia and protects against focal ischemia in the striatum (Lawrence et al., 1996). Our results are also consistent with the finding that permanent focal ischemic lesions are attenuated in Bcl-2 overexpressing mice and that neurons that survive ischemic lesions in vivo show upregulation of Bcl-2 (Martinou et al., 1994; Chen et al., 1995). Overexpression of Bcl-2 also prolongs survival and attenuates motor neuron degeneration in a transgenic animal model of amyotrophic lateral sclerosis (Kostic et al., 1997).

The present results suggest that expression of Bcl-2 or administration of Bcl-2 mimics might be useful in the treatment of PD. Evidence implicating apoptosis in PD is controversial. Some studies found evidence for apoptosis based on morphological criteria or in situ end labeling (Mochizuki et al., 1996; Anglade et al., 1997), whereas others did not (Kosel et al., 1997). An increase in Bcl-2 protein was found in caudate and putamen of PD patients (Mogi et al., 1996). Whether neuronal death in PD occurs by either apoptosis or necrosis, our present results suggest that Bcl-2 may exert neuroprotective effects. Furthermore, recent evidence indicates that it can promote regeneration of severed retinal axons in vitro, independent of its anti-apoptotic effects (Chen et al., 1997). This suggests that Bcl-2 might exert both neuroprotective effects, as well as restorative effects, in promoting regrowth of dopaminergic axons in PD.

\section{Addendum}

While this manuscript was in review, others have found that Bcl-2 overexpressing mice are protected against acute MPTP-induced dopamine depletion (Offen et al., 1998).

\section{REFERENCES}

Anglade P, Vyas S, Javoy-Agid F, Herrero MT, Michel PP, Marquez J, Mouatt-Prigent A, Ruberg M, Hirsch EC, Agid Y (1997) Apoptosis and autophagy in nigral neurons of patients with Parkinson's disease. Histol Histopathol 12:25-31.

Antonsson B, Conti F, Ciavatta AM, Montessuit S, Lewis S, Martinou I, Bernasconi L, Bernard A, Mermod J-J, Mazzei G, Maundrell K, Gambale F, Sadoul R, Martinou J-C (1997) Inhibition of Bax channelforming activity by Bcl-2. Science 277:370-372.

Baffy G, Miyashita T, Williamson JR, Reed JC (1993) Apoptosis induced by withdrawal of interleukin-3 (IL-3) and an IL-3-dependent hematopoietic cell line is associated with repartitioning of intracellular calcium and is blocked by enforced $\mathrm{Bcl}-2$ oncoprotein production. J Biol Chem 268:6511-6519.

Beal MF, Kowall NW, Swartz KJ, Ferrante R (1990) Homocysteic acid striatal lesions in rats spare somatostatin-neuropeptide $\mathrm{Y}$ neurons. Neurosci Lett 108:36-42.

Bloem BR, Irwin I, Buruma OJS, Haan J, Roos RAC, Tetrud JW, Langston JW (1990) The MPTP model: versatile contributions to the treatment of idiopathic Parkinson's disease. J Neurol Sci 97:273-293.

Bredesen DE (1995) Neural apoptosis. Ann Neurol 38:839-351.

Chen DF, Schneider GE, Martinou J-C, Tonegawa S (1997) Bcl-2 pro- 
motes regeneration of severed axons in mammalian CNS. Nature 385:434-439.

Chen J, Graham SH, Chan PH, Lan J, Zhou RL, Simon RP (1995) Bcl-2 is expressed in neurons that survive focal ischemia in the rat. NeuroReport 6:394-398.

Chinnaiyan AM, Orth K, O'Rourke K, Duan H, Poirier GG, Dixit VM (1996) Molecular ordering of the cell death pathway. J Biol Chem 271:4573-4576.

Cleeter MJW, Cooper JM, Schapira AHV (1992) Irreversible inhibition of mitochondrial complex I by 1-methyl-4-phenylpyridium: evidence for free radical involvement. J Neurochem 58:786-789.

Ellerby LM, Ellerby HM, Park SM, Holleran AL, Murphy AN, Fiskum G, Kane DJ, Testa MP, Kayalar C, Bredesen DE (1996) Shift of the cellular oxidation-reduction potential in neural cells expressing bcl-2. J Neurochem 67:1259-1267.

Garland JM, Halestrap A (1997) Energy metabolism during apoptosis. J Biol Chem 272:4680-4688.

Hantraye P, Brouillet E, Ferrante R, Palfi S, Dolan R, Matthews RT, Beal MF (1996) Inhibition of neuronal nitric oxide synthase prevents MPTP-induced parkinsonism in baboons. Nat Med 2:1017-1021.

Hartley A, Stone JM, Heron C, Cooper JM, Schapira AHV (1994) Complex I inhibitors induced dose-dependent apoptosis in PC12 cells: relevance to Parkinson's disease. J Neurochem 63:1987-1990.

Harvey NL, Butt AJ, Kumar S (1997) Functional activation of Nedd2/ ICH-1 (Caspase-2) is an early process in apoptosis. J Biol Chem 272:13134-13139.

Hasegawa E, Takeshige K, Oishi T, Murai Y, Minakami S (1990) 1-Methyl-4-phenylpyridinium $\left(\mathrm{MPP}^{+}\right)$induces NADH-dependent superoxide formation and enhances NADH-dependent lipid peroxidation in bovine heart submitochondrial particles. Biochem Biophys Res Commun 170:1049-1055.

Hennet T, Bertoni G, Richter C, Peterhans E (1993) Expression of Bcl-2 protein enhances the survival of mouse fibrosarcoid cells in tumor necrosis factor-mediated cytotoxicity. Cancer Res 53:1456-1460.

Hockenbery DM, Oltvai ZN, Yin X-M, Milliman CL, Korsmeyer SJ (1993) Bcl-2 functions in an antioxidant pathway to prevent apoptosis. Cell 75:241-251.

Jackson-Lewis V, Jakowec M, Burke RE, Przedborski S (1995) Time course and morphology of dopaminergic neuronal death caused by the neurotoxin 1-methyl-4-phenyl-1,2,3,6-tetrahydropyridine. Neurodegeneration 4:257-269.

Javitch JA, Blaustein RO, Snyder SH (1983) $\left[{ }^{3} \mathrm{H}\right]$ mazindol binding associated with neuronal dopamine uptake sites in corpus striatum membrane. Eur J Pharmacol 90:461-462.

Kane DJ, Sarafian TA, Anton R, Hahn H, Butler Gralla E, Selverstone Valentine J, Ord T, Bredesen DE (1993) Bcl-2 inhibition of neural death: decreased generation of reactive oxygen species. Science 262:1274-1277.

Kane DJ, Ord T, Anton R, Bredesen DE (1995) Expression of $b c l-2$ inhibits necrotic neural cell death. J Neurosci Res 40:269-275.

Kharbanda S, Pandey P, Schofield L, Israels S, Roncinske R, Yoshida K, Bhartia A, Yuan Z-M, Saxena S, Weichselbaum R, Nalin C, Kufe D (1997) Role for Bcl- $\mathrm{x}_{\mathrm{L}}$ as an inhibitor of cytosolic cytochrome C accumulation in DNA damage-induced apoptosis. Proc Natl Acad Sci USA 94:6939-6942.

Kluck RM, Bossy-Wetzel E, Green DR, Newmeyer DD (1997) The release of cytochrome $\mathrm{c}$ from mitochondria: a primary site for $\mathrm{Bcl}-2$ regulation of apoptosis. Science 275:1132-1136.

Kosel S, Egensperger R, von Eitzen U, Mehraein P, Graeber MB (1997) On the question of apoptosis in the parkinsonian substantia nigra. Acta Neuropathol (Berl) 93:105-108.

Kostic V, Jackson-Lewis V, de Bilbao F, Dubois-Dauphin M, Przedborski S (1997) Bcl-2: prolonging life in a transgenic mouse model of familial amyotrophic lateral sclerosis. Science 277:559-562.

Krajewski S, Tanaka S, Takayama S, Schibler MJ, Fenton W, Reed JC (1993) Investigation of the subcellular distribution of the $b c l-2$ oncoprotein: residence in the nuclear envelope, endoplasmic reticulum, and outer mitochondrial membranes. Cancer Res 53:4701-4714.

Kumar S, Kinoshita M, Noda M, Copeland NG, Jenkins NA (1994) Induction of apoptosis by the mouse Nedd2 gene, which encodes a protein similar to the product of the Caenorhabditis elegans cell death gene ced-3 and the mammalian IL- $1 \beta$-converting enzyme. Genes Dev 8:1613-1626.

Lawrence MS, Ho DY, Sun GH, Steinberg GK, Sapolsky RM (1996) Overexpression of Bcl-2 with herpes simplex virus vectors protects CNS neurons against neurological insults in vitro and in vivo. J Neurosci 16:486-496.

Liu X, Kim CN, Yang J, Jemmerson R, Wang X (1996) Induction of apoptotic program in cell-free extracts: requirement for dATP and cytochrome c. Cell 86:147-157.

Martinou J-C, Dubois-Dauphin M, Staple JK, Rodriguez I, Frankowski H, Missotten M, Albertini P, Talabot D, Catsicas S, Pietra C, Huarte J (1994) Overexpression of BCL-2 in transgenic mice protects neurons from naturally occurring cell death and experimental ischemia. Neuron 13:1017-1030.

Minn AJ, Velez P, Schendel SL, Liang H, Muchmore SW, Feslk SW, Fill M, Thompson CB (1997) Bcl- $\mathrm{x}_{\mathrm{L}}$ forms an ion channel in synthetic lipid membranes. Nature 385:353-357.

Mochizuki H, Goto K, Mori H, Mizuno Y (1996) Histochemical detection of apoptosis in Parkinson's disease. J Neurol Sci 137:120-123.

Mogi M, Harada M, Kondo T, Mizuno Y, Narabayashi H, Riederer P, Nagatsu T (1996) Bcl-2 protein is increased in the brain from parkinsonian patients. Neurosci Lett 215:137-139.

Murphy AN, Bredesen DE, Cortopassi G, Wang E, Fiskum G (1996) Bcl-2 potentiates the maximal calcium uptake capacity of neural cell mitochondria. Proc Natl Acad Sci USA 93:9893-9898.

Myers KM, Fiskum G, Liu Y, Simmens SJ, Bredesen DE, Murphy AN (1995) Bcl-2 protects neural cells from cyanide/aglycemia-induced lipid oxidation, mitochondrial injury, and loss of viability. J Neurochem 65:2432-2440.

Offen D, Beart PM, Cheung NS, Pascoe CJ, Hochman A, Gorodin S, Melamed E, Bernard R, Bernard O (1998) Transgenic mice expressing human Bcl-2 in their neurons are resistant to 6-hydroxydopamine and 1-methyl-4-phenyl-1,2,3,6-tetrahydropyridine neurotoxicity. Proc Natl Acad Sci USA 95:5789-5794.

Pan HS, Frey KA, Young AB, Penney JB (1983) Changes in $\left[{ }^{3} \mathrm{H}\right]$ muscimol binding in substantia nigra, entopenduncular nucleus, globus pallidus, and thalamus and striatal lesions as demonstrated by quantitive receptor autoradiography. J Neurosci 3:1189-1198.

Penney JB, Pan HS, Young AB, Frey KA, Dauth GW (1981) Quantitative autoradiography of $\left[{ }^{3} \mathrm{H}\right]$ muscimol binding in rat brain. Science 214:1036-1038.

Przedborski S, Kostic V, Jackson-Lewis V, Naini AB, Simonetti S, Fahn S, Carlson E, Epstein CJ, Cadet JL (1992) Transgenic mice with increased $\mathrm{Cu} / \mathrm{Zn}$-superoxide dismutase activity are resistant to $N$-methyl-4-phenyl-1,2,3,6-tetrahydropyridine-induced neurotoxicity. J Neurosci 12:1658-1667.

Przedborski S, Jackon-Lewis V, Yokoyama R, Shibata T, Dawson VL, Dawson TM (1996) Role of neuronal nitric oxide in 1-methyl-4phenyl-1,2,3,6-tetrahydropyridine (MPTP)-induced dopaminergic neurotoxicity. Proc Natl Acad Sci USA 93:4565-4571.

Schendel SL, Xie Z, Oblatt Montal M, Matsuyama S, Montal M, Reed JC (1997) Channel formation by antiapoptotic protein Bcl-2. Proc Natl Acad Sci USA 94:5113-5118.

Schulz JB, Matthews RT, Muqit MMK, Browne SE, Beal MF (1995) Inhibition of neuronal nitric oxide synthase by 7-nitroindazole protects against MPTP-induced neurotoxicity in mice. $\mathrm{J}$ Neurochem 64:936-939.

Shimizu S, Eguchi Y, Kamike W, Funahashi Y, Mignon A, Lacronique V, Matsuda H, Tsujimoto Y (1998) Bcl-2 prevents apoptotic mitochondrial dysfunction by regulating proton flux. Proc Natl Acad Sci USA 95:1455-1459.

Smets LA, Van der Berg J, Acton D, Top B, van Rooij H, Verwijs-Janssen M (1994) BCL-2 expression and mitochondrial activity in leukemic cells with different sensitivity to glucocorticoid-indued apoptosis. Blood 5:1613-1619.

Srinivasan A, Foster LM, Testa M-P, Ord T, Keane RW, Bredesen DE, Kayalar C (1996) Bcl-2 expression in neural cells blocks activation of ICE/CED-3 family proteases during apoptosis. J Neurosci 16:5654-5660.

Sriram K, Pai KS, Boyd MR, Ravindranath V (1997) Evidence for generation of oxidative stress in brain by MPTP: in vitro and in vivo studies in mice. Brain Res 749:44-52.

Storey E, Cipolloni PB, Ferrante RJ, Kowall NW, Beal MF (1994) Movement disorder following excitotoxin lesions in primates. NeuroReport 5:1259-1261.

Susin SA, Zamzami N, Castedo M, Hirsch T, Marchetti P, Macho A, Daugas E, Geuskens M, Kroemer G (1996) Bcl-2 inhibits the mitochondrial release of an apoptogenic protease. $J$ Exp Med 184:1331-1341. 
Tatton NA, Kish SJ (1997) In situ detection of apoptotic nuclei in the substantia nigra compacta of 1-methyl-4-phenyl-1,2,3,6-tetrahydropyridine-treated mice using terminal deoxynucleotidyl transferase labelling and acridine orange staining. Neuroscience 77:1037-1048.

Tipton KF, Singer TP (1993) Advances in our understanding of the mechanisms of the neurotoxicity of MPTP and related compounds. J Neurochem 61:1191-1206.

Troy CM, Stefanis L, Greene LA, Shelanski ML (1997) Nedd2 is required for apoptosis after trophic factor withdrawal, but not superoxide dismutase (SOD1) downregulation, in sympathetic neurons and PC12 cells. J Neurosci 17:1911-1918.

Tyurina YY, Tyurin VA, Carta G, Quinn PJ, Schor NF, Kagan VE (1997) Direct evidence for antioxidant effect of Bcl-2 in PC12 rat pheochromocytoma cells. Arch Biochem Biophys 344:413-423.

Vander Heiden MG, Chandel NS, Williamson EK, Schumacker PT, Thompson CB (1997) $\mathrm{Bcl}-\mathrm{x}_{\mathrm{L}}$ regulates the membrane potential and volume homeostasis of mitochondria. Cell 91:627-637.
Voehringer DW, McConkey DJ, McDonnell TJ, Meyn RE (1998) Bcl-2 expression causes redistribution of glutathione to the nucleus. Proc Natl Acad Sci USA 95:2956-2960.

Wang H-G, Rapp UR, Reed JC (1996) Bcl-2 targets the protein kinase Raf-1 to mitochondria. Cell 87:629-638.

White MJ, Chen J, Zhu L, Irvin S, Sinor A, DiCaprio MJ, Jin K, Greenberg DA (1997) A Bcl-2 antisense oligonucleotide increases $\alpha$-amino-3-hydroxy-5-methylisoxazole-4-propionic acid (AMPA) toxicity in cortical cultures. Ann Neurol 42:580-587.

Yang J, Liu X, Bhalla K, Kim CN, Ibrado AM, Cai J, Peng T-I, Jones DP, Wang X (1997) Prevention of apoptosis by Bcl-2: release of cytochrome c from mitochondria blocked. Science 275:1129-1136.

Zamzami N, Susin SA, Marchetti P, Hirsch T, Gomez-Monterrey I, Castedo M, Kroemer G (1996) Mitochondrial control of nuclear apoptosis. J Exp Med 183:1533-1544.

Zou H, Henzel WJ, Liu X, Lutschg A, Wang X (1997) Apaf-1, a human protein homologous to $C$. elegans CED-4: participates in cytochrome c-dependent activation of caspase-3. Cell 90:405-413. 